\title{
Optimization of reaction parameters in hydrothermal synthesis: a strategy towards the formation of CuS hexagonal plates
}

Yow Loo Auyoong ${ }^{1,2+}$, Pei Lay Yap ${ }^{1,2 \dagger}$, Xing Huang ${ }^{3 \dagger}$ and Sharifah Bee Abd Hamid ${ }^{1 * \dagger}$

\begin{abstract}
Background: For decades, copper sulphide has been renowned as the superior optical and semiconductor materials. Its potential applications can be ranged from solar cells, lithium-ion batteries, sensors, and catalyst systems. The synthesis methodologies of copper sulphide with different controlled morphology have been widely explored in the literature. Nevertheless, the understanding on the formation chemistry of CuS is still limited. The ultimate approach undertaking in this article is to investigate the formation of CuS hexagonal plates via the optimization of reaction parameters in hydrothermal reaction between copper (II) nitrate and sodium thiosulphate without appending any assistant agent.
\end{abstract}

Results: Covellite (CUS) hexagonal plates were formed at copper ion: thiosulphate ion $\left(\mathrm{Cu}^{2+}: \mathrm{S}_{2} \mathrm{O}_{3}{ }^{2-}\right)$ mole ratio of $1: 2$ under hydrothermal treatment of $155^{\circ} \mathrm{C}$ for 12 hours. For synthesis conducted at reaction temperature lower than $155^{\circ} \mathrm{C}$, copper sulphate $\left(\mathrm{CuSO}_{4}\right)$, krohnite $\left(\mathrm{NaCu}_{2}\left(\mathrm{SO}_{4}\right)\left(\mathrm{H}_{2} \mathrm{O}\right)_{2}\right]$ and cyclooctasulphur $\left(\mathrm{S}_{8}\right)$ were present as main impurities with covellite (CUS). When $\mathrm{Cu}^{2+}: \mathrm{S}_{2} \mathrm{O}_{3}{ }^{2-}$ mole ratio was varied to $1: 1$ and 1:1.5, phase pure plate-like natrochalcite $\left[\mathrm{NaCu}_{2}\left(\mathrm{SO}_{4}\right)\left(\mathrm{H}_{2} \mathrm{O}\right)\right]$ and digenite $\left(\mathrm{Cu}_{9} \mathrm{~S}_{5}\right)$ were produced respectively. Meanwhile, mixed phases of covellite (CuS) and cyclooctasulphur $\left(\mathrm{S}_{8}\right)$ were both identified when $\mathrm{Cu}^{2+}: \mathrm{S}_{2} \mathrm{O}_{3}{ }^{2-}$ mole ratio was varied to 1: 2.5, 1: 3 and 1: 5 as well as when reaction time was shortened to 1 hour.

Conclusions: CuS hexagonal plates with a mean edge length of $1 \mu \mathrm{m}$, thickness of $100 \mathrm{~nm}$ and average crystallite size of approximately (45 \pm 2$) \mathrm{nm}$ (Scherrer estimation) were successfully synthesized via assisting agent- free hydrothermal method. Under a suitable $\mathrm{Cu}^{2+}: \mathrm{S}_{2} \mathrm{O}_{3}{ }^{2-}$ mole ratio, we evidenced that the formation of covellite (CUS) is feasible regardless of the reaction temperature applied. However, a series of impurities were attested with CuS if reaction temperature was not elevated high enough for the additional crystallite phase decomposition. It was also identified that $\mathrm{Cu}^{2+}: \mathrm{S}_{2} \mathrm{O}_{3}{ }^{2-}$ mole ratio plays a vital role in controlling the amount of cyclooctasulphur $\left(\mathrm{S}_{8}\right)$ in the final powder obtained. Finally, reaction time was recognized as an important parameter in impurity decomposition as well as increasing the crystallite size and crystallinity of the CUS hexagonal plates formed.

\section{Background}

Copper sulphides have received momentous attention from both chemists and material scientists owing to its unique physical and chemical properties [1-3] for potential applications in solar cells, lithium-ion batteries, sensors, and catalysts [4-8]. To date, various copper sulphide of specific morphologies such as flakes-like [9],

\footnotetext{
*Correspondence: sharifahbee@um.edu.my

${ }^{\dagger}$ Equal contributors

'COMBICAT Laboratory, Nanotechnology \& Catalysis Research Centre (NANOCAT), University of Malaya, Kuala Lumpur 50603, Malaysia Full list of author information is available at the end of the article
}

rod-like [10], needle-like [11], wires-like [12,13], tubeslike [14], or even spheres-like [15] have been reported. Nonetheless, the significance of plate-like structured materials is remarkably manifested in the literature as promising building blocks for nanodevices with its controlled crystal orientation due to their anisotropic structures [16-19]. In fact, a great deal of effort has been dedicated to the synthesis of $\mathrm{CuS}$ with plate-like structure, particularly hexagonal plate-shaped. Du et al. have revealed that shape-controlled hexagonal $\mathrm{CuS}$ can be prepared by employing copper acetate and carbon disulphide with toluene and hexadecylamine as assisting

\section{(Chemistry Central}


agents via a solvothermal process [20]. CuS hexagonal plates were fabricated using $\mathrm{CTAB}$ and nitric acid as assisting agent on top of copper (II) chloride and sodium thiosulphate as precursors via a hydrothermal method [21]. Y. Liu et al. have synthesized CuS hexagonal plates by applying hexadecylamine, ethanol, potassium ethylxanthate and copper nitrate through a facile solution route [22]. A mixed-mode method of wet chemical and modified hydrothermal techniques which employed copper (II) chloride, acetylacetone, sodium acetate, dichloromethane, ethanol, and sodium hydroxide as precursors was also demonstrated by Basu et al. to achieve the formation of $\mathrm{CuS}$ with hexagonal stacked plates morphology [23]. Despite the enormous synthesis methods developed in fabricating hexagonal shaped $\mathrm{CuS}$, it could be seen that the formation of $\mathrm{CuS}$ is not fully understood due to the use of multiple solvent phases or additional assisting agent which is present in the reactions. This factor can eventually result in a complicated series of reaction occurring in the synthesis which leads to difficulty in explaining the $\mathrm{CuS}$ formation.

Generally, the ultimate challenge in any synthesis approach is to identify the role of each reaction parameter in controlling the morphology and crystal structure of the final products obtained. This understanding is essential in distinguishing and establishing the reaction mechanism for the targeted compound formation. Hence, our approach is focusing on the investigation of $\mathrm{CuS}$ hexagonal plates formation via the optimization of reaction parameters in hydrothermal reactions between copper (II) nitrate and sodium thiosulphate without appending any assistant agent. Hydrothermal method is selected in this work because it requires no complex organometallic precursor in the reaction [24,25]. Furthermore, highly crystalline products with controlled morphology can be easily achieved in hydrothemal treatment by varying the specific source species, reaction temperature, reaction time and etc. [26,27]. In the entire methodology, we have chosen mild reactants like copper (II) nitrate and sodium thiosulphate as the precursors; unlike the case of hydrogen sulphide [28,29], ammonium sulphide [30] and sodium sulphide $[14,31,32]$ which are highly reactive and nasty in handling during the experiment.

In the present study, covellite $(\mathrm{CuS})$ is identified as a thermodynamically stable compound in which its formation is feasible at appropriate $\mathrm{Cu}^{2+}: \mathrm{S}_{2} \mathrm{O}_{3}{ }^{2-}$ mole ratio even at room temperature condition. However, a series of impurities were attested with $\mathrm{CuS}$ if reaction temperature was not elevated high enough for their decompositions. With the aim to further comprehend $\mathrm{CuS}$ hexagonal plates formation, the roles of reaction temperature, $\mathrm{Cu}^{2+}: \mathrm{S}_{2} \mathrm{O}_{3}{ }^{2-}$ mole ratio and reaction time towards the crystal structures and morphologies of the final products formed were systematically investigated.
The possible formation and growth of $\mathrm{CuS}$ hexagonal plates during the hydrothermal treatment were also proposed based on the presence of $\mathrm{Cu}$ (I) instead of $\mathrm{Cu}$ (II) species in the crystal structure of covellite $(\mathrm{CuS})$ [33]. The entire methodology described herein has provided us further insight on the use of facile hydrothermal technique in studying the reactions between aqueous solution phase reactants as well as synthesizing highly crystalline phase pure covellite $(\mathrm{CuS})$ hexagonal plates without any assisting agent.

\section{Results and discussion}

Structural and compositional analyses of CuS hexagonal plates

The crystal phase of the product formed in the reaction of copper nitrate and sodium thiosulphate was identified by powder XRD technique. The powder XRD pattern as illustrated in Figure 1 shows the crystal phase of product formed at $\mathrm{Cu}^{2+}: \mathrm{S}_{2} \mathrm{O}_{3}{ }^{2-}$ mole ratio of $1: 2$ under $155^{\circ} \mathrm{C}$. All the characteristic peaks in this pattern correspond well to the hexagonal phase covellite in the space group of $P 63 / \mathrm{mmc}$ which can be well indexed to PDF 06-464 with $\mathrm{a}=3.792 \AA$ and $\mathrm{c}=16.34 \AA$. The diffractogram of this compound exhibits no XRD peaks arising from impurities of $\mathrm{CuO}, \mathrm{S}$, and other $\mathrm{Cu}_{\mathrm{x}} \mathrm{S}$. This denotes high phase purity of the CuS obtained in the facile hydrothermal batch route developed.

The morphology of the fabricated sample was characterized by FESEM technique (Figure 2a). It is clearly shown that the powder obtained exhibits particles with hexagonal plate structure. The hexagonal shape plates assembled, interlaced and perpendicular to one another. It could be observed that the hexagonal plates have a mean edge length of $1 \mu \mathrm{m}$ and an average thickness of

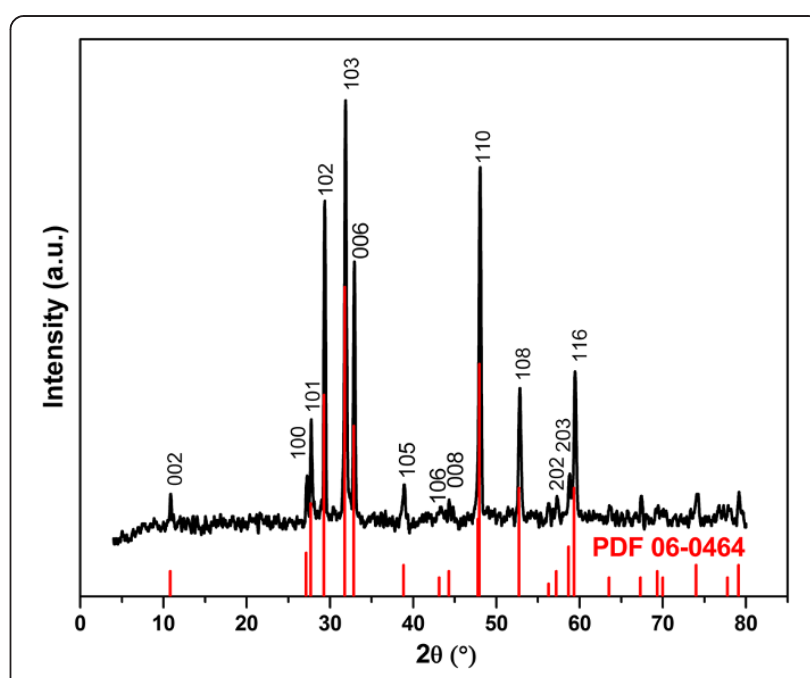

Figure 1 Powder XRD pattern of CuS. Synthesis was conducted at $\mathrm{Cu}^{2+}: \mathrm{S}_{2} \mathrm{O}_{3}{ }^{2-}$ mole ratio of $1: 2$ at $155^{\circ} \mathrm{C}$ for 12 hours. 


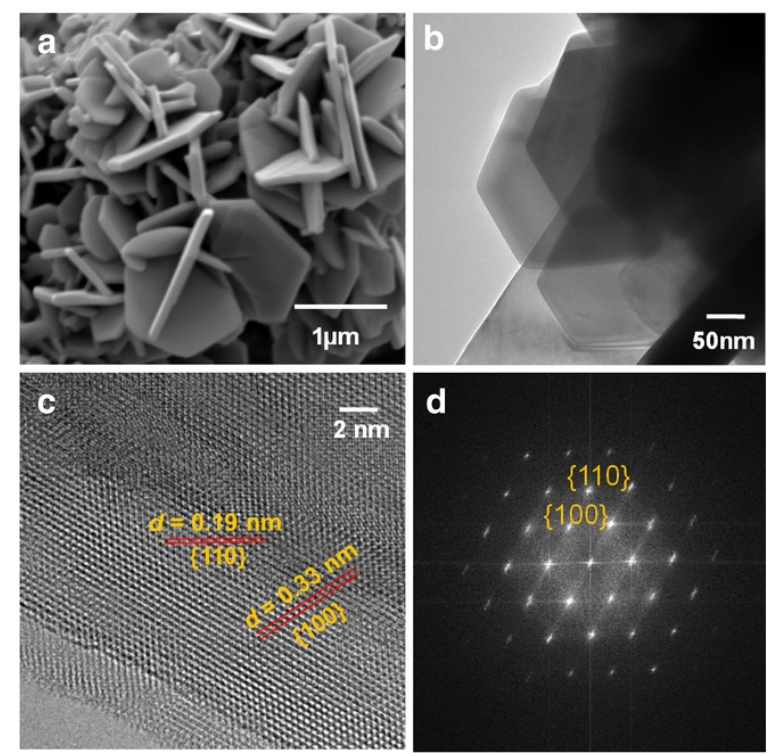

Figure 2 Electron Micrographs of CuS hexagonal plates. FESEM image (a), TEM image (b), HRTEM image with incident beam from the $<001>$ direction (c) and Fast Fourier Transform (FFT) pattern (d) of CuS hexagonal plates.

ca. $100 \mathrm{~nm}$. The hexagonal plate architecture found can be significantly related to the formation of the hexagonal phase of covellite in which it correlates well with the single phase of covellite determined by powder XRD analysis. The insight of the hexagonal plate microstructure was also examined by employing TEM and HRTEM analyses. The TEM image as depicted in Figure $2 \mathrm{~b}$ vividly shows the stack layers orientation of many $\mathrm{CuS}$ plates with hexagonal structure. The observation of hexagonal shaped particle from TEM analysis agrees well with the morphology determined from FESEM images. Figure $2 \mathrm{c}$ depicts the HRTEM image of the hexagonal shaped particle. From the well resolved 2D lattice fringes of the $\mathrm{CuS}$ hexagonal plate measured, two adjacent lattice spacings of $0.19 \mathrm{~nm}$ and $0.33 \mathrm{~nm}$ have been identified from the image. It is important to note that both of the lattice spacings of $0.19 \mathrm{~nm}$ and $0.33 \mathrm{~nm}$ relate well to the $\{110\}$ and $\{100\}$ plane spacings of hexagonal $\mathrm{CuS}$ respectively. A Fast Fourier Transform (FFT) pattern of the as-synthesized $\mathrm{CuS}$ hexagonal plate is also captured in Figure 2d. The ordered hexagonal-like spot arrays visibly illustrated in the FFT pattern again confirmed the formation of $\mathrm{CuS}$ with hexagonal shape. All these results strongly signify the single crystallinity of the $\mathrm{CuS}$ hexagonal plates formed in this hydrothermal synthesis.

The bulk elemental composition of the as-synthesized powder was analyzed by X-ray fluorescence (XRF) technique. XRF analysis revealed that the bulk composition of the respective powder consists of only $\mathrm{Cu}$ and $\mathrm{S}$ in which the $\mathrm{Cu}: \mathrm{S}$ atomic ratio calculated is $1: 1.04$. In addition, EDX analysis was conducted to probe the localized surface elemental composition of the hexagonal plates. Figure 3 depicts the multiple EDX analysis scanned at one area and different spots for the hexagonal plates synthesized. From the numerous scans of EDX spectra, the powder is found to compose $\mathrm{Cu}$ and $\mathrm{S}$ elements in which no significant contamination from other elements can be detected. As tabulated in Table 1, the respective quantified EDX spectra disclose the average atomic composition of $\mathrm{Cu}: \mathrm{S}$ is closed to each other, reaching average percentage of approximately 50: 50 . Both of the results attained from XRF and EDX analyses are complementary to each other and the atomic ratio of $\mathrm{Cu}$ and $\mathrm{S}$ evaluated is consistent with the ideal nominal stoichiometric ratio of covellite which is 1: 1 for $\mathrm{Cu}$ : S. Therefore, the bulk and localized distributions of $\mathrm{Cu}$ and $\mathrm{S}$ are in good agreement with the powder XRD and HRTEM analysis in which merely pure phase covellite $(\mathrm{CuS})$ is found in the hexagonal plates.

\section{Role of reaction temperature in hydrothermal synthesis} In order to attain a better understanding on the formation of phase pure $\mathrm{CuS}$ hexagonal plate, several experiments were carried out at different synthesis temperatures with $\mathrm{Cu}^{2+}: \mathrm{S}_{2} \mathrm{O}_{3}{ }^{2-}$ mole ratio fixed at 1: 2 for 12 hours. Figures 4, 5 and 6 depict the powder XRD patterns of crystalline compounds formed at 25.0, 65.0, 95.0, 125.0 and $175.0^{\circ} \mathrm{C}$. At reaction temperature of $25^{\circ} \mathrm{C}$, mixed phases of copper sulphate $\left[\mathrm{CuSO}_{4}\right]$, krohnite $\left[\mathrm{NaCu}_{2}\left(\mathrm{SO}_{4}\right)\left(\mathrm{H}_{2} \mathrm{O}\right)_{2}\right]$, cyclooctasulphur $\left[\mathrm{S}_{8}\right]$ as well as covellite [CuS] are observed in the powder XRD diffractogram. This observation strongly suggests that $\mathrm{CuS}$ is a thermodynamically stable compound in which under a suitable $\mathrm{Cu}^{2+}: \mathrm{S}_{2} \mathrm{O}_{3}{ }^{2-}$ mole ratio (specifically 1 : 2 in this study), its formation is feasible even under room temperature condition. The morphology of this mixed phase powder is shown in Figure 4b. The morphology of this sample resembles the shape of paper flower with many uniform clusters. Each cluster of the flower is surrounded by 3 or 4 thin bracts of petals.

As reaction temperature was increased to $65.0^{\circ} \mathrm{C}$, both of the $\mathrm{CuS}$ and $\mathrm{S}_{8}$ phases are identified while $\mathrm{NaCu}_{2}\left(\mathrm{SO}_{4}\right)$ $\left(\mathrm{H}_{2} \mathrm{O}\right)_{2}$ and $\mathrm{CuSO}_{4}$ disappeared from the diffractogram. For $\mathrm{NaCu}_{2}\left(\mathrm{SO}_{4}\right)\left(\mathrm{H}_{2} \mathrm{O}\right)_{2}$ and $\mathrm{CuSO}_{4}$ phases, they are determined to be slightly and highly soluble in water respectively $[34,35]$. For both $\mathrm{CuS}\left(\mathrm{K}_{\mathrm{sp}}=8 \times 10^{-37}\right)$ and $\mathrm{S}_{8}$, they tend to have low solubility in water even with solution temperature elevation [36,37]. A preferential dissolution of $\mathrm{NaCu}_{2}\left(\mathrm{SO}_{4}\right)\left(\mathrm{H}_{2} \mathrm{O}\right)_{2}$ and $\mathrm{CuSO}_{4}$ occurred in water during the reaction. Thus, the retention of both $\mathrm{CuS}$ and $\mathrm{S}_{8}$ as well as the disappearance of $\mathrm{NaCu}_{2}\left(\mathrm{SO}_{4}\right)\left(\mathrm{H}_{2} \mathrm{O}\right)_{2}$ and $\mathrm{CuSO}_{4}$ in the product are closely related to their solubility in water at increasing temperature. The morphology of the sample has changed from the flower-like (at $25.0^{\circ} \mathrm{C}$ ) to 

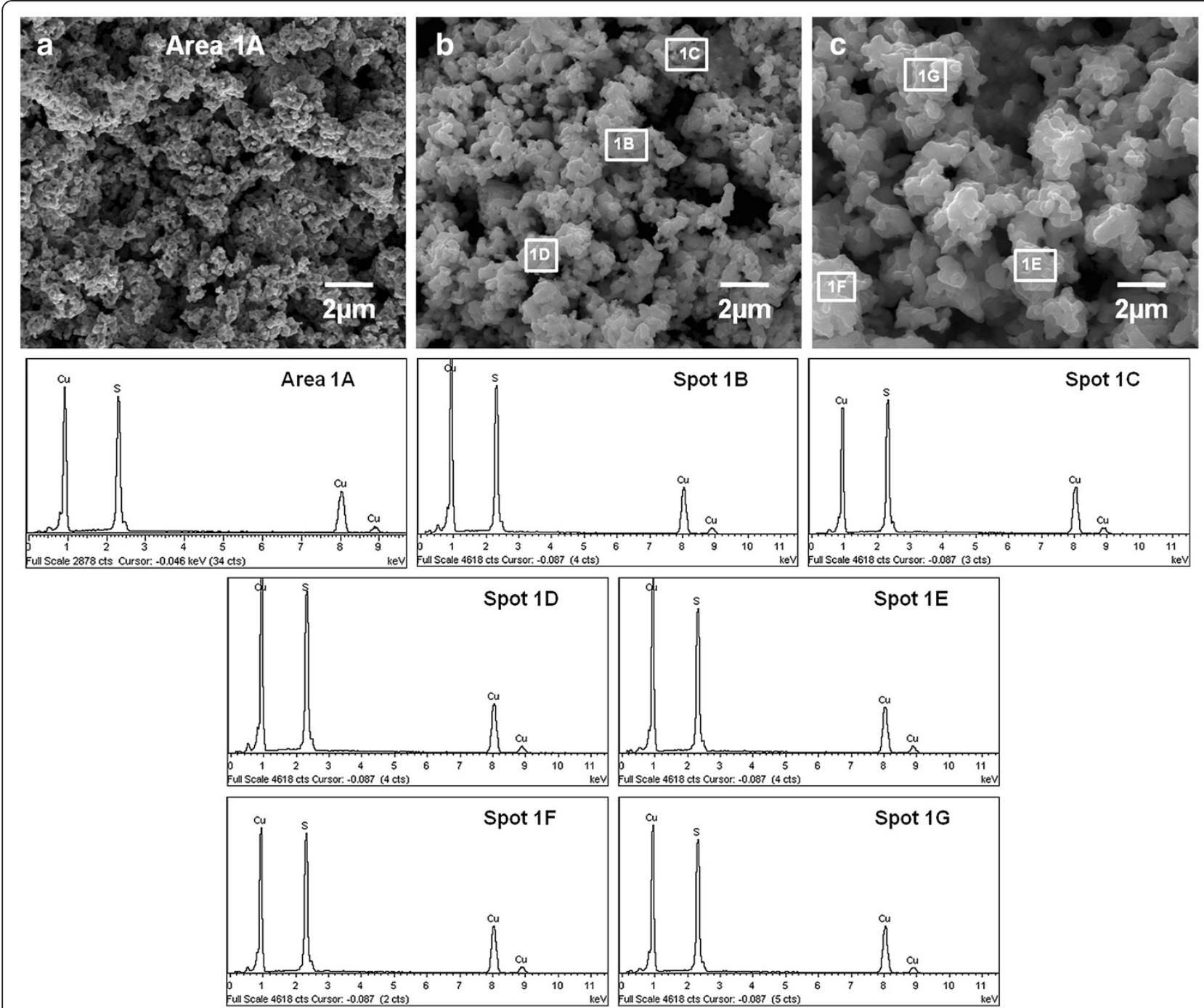

Figure 3 EDX analysis on CuS hexagonal plates. Area analysis (a), spot analysis (b) and (c) of CuS hexagonal plates. The related EDX spectra are labelled as Area 1A, Spot 1B to Spot 1G.

ball-like structures as indicated in Figure 5b. As reaction temperature was further increased to 95.0 and $125.0^{\circ} \mathrm{C}$, the $\mathrm{CuS}$ phase is still accompanied by $\mathrm{S}_{8}$ phase in the powder XRD patterns. Even with relatively higher temperature applied, the crystalline $S_{8}$ peak at $2 \theta=23^{\circ}$ is becoming less intense as compared to the diffractogram at $65.0^{\circ} \mathrm{C}$. This indicates that $\mathrm{S}_{8}$ impurity has not been completely decomposed even at $125^{\circ} \mathrm{C}$. Moreover, the morphology of the ball-like structures synthesized at 95.0 and $125.0^{\circ} \mathrm{C}$ remained similar as the product formed at $65.0^{\circ} \mathrm{C}$. This result signifies that the growth of hexagonal plate-like structure cannot be achieved if reaction temperature is not elevated high enough to decompose the $\mathrm{S}_{8}$ impurity phase.

In fact, the decomposition of $\mathrm{S}_{8}$ is estimated at $149.5^{\circ} \mathrm{C}$ in which a complete breaking of crown $\mathrm{S}_{8}$ ring might be expected [38]. In order to investigate the optimum temperature in eliminating $\mathrm{S}_{8}$ phase without
Table 1 EDX analysis on CuS hexagonal plates

\begin{tabular}{ccc}
\hline Area/ Spot & Cu Atomic \% & S Atomic \% \\
\hline Area 1A & 51.53 & 48.47 \\
Spot 1B & 48.28 & 51.72 \\
Spot 1C & 51.40 & 48.60 \\
Spot 1D & 48.08 & 51.92 \\
Spot 1E & 49.11 & 50.89 \\
Spot 1 F & 50.55 & 49.45 \\
Spot 1G & 50.24 & 49.76 \\
Average & $\mathbf{4 9 . 8 8}$ & $\mathbf{5 0 . 1 2}$ \\
\hline
\end{tabular}

Synthesis was conducted at $155^{\circ} \mathrm{C}$ with $\mathrm{Cu}^{2+}: \mathrm{S}_{2} \mathrm{O}_{3}{ }^{2-}$ mole ratio of $1: 2$ for 12 hours with reference to Figure 3 . 


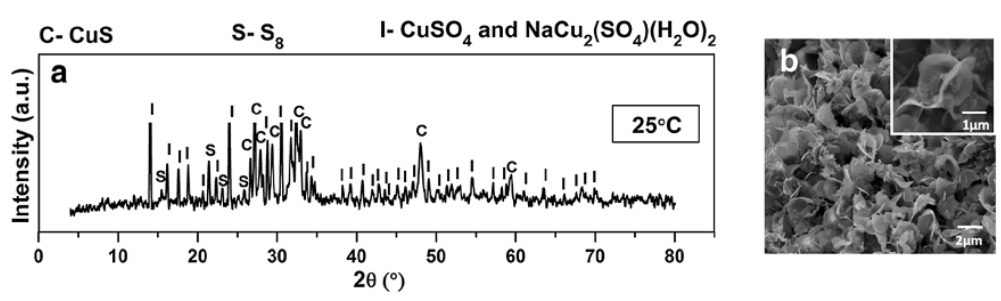

Figure 4 Product prepared at $25^{\circ} \mathrm{C}$. Powder XRD pattern (a) and FESEM images (b) of product formed at $25^{\circ} \mathrm{C}$ with $\mathrm{Cu}^{2+}: \mathrm{S}_{2} \mathrm{O}_{3}{ }^{2-}$ mole ratio of 1: 2 for 12 hours.

affecting $\mathrm{CuS}$ phase in the powder, phase pure $\mathrm{CuS}$ hexagonal plates obtained at $\mathrm{Cu}^{2+}: \mathrm{S}_{2} \mathrm{O}_{3}{ }^{2-}$ mole ratio of 1 : 2 was subjected to thermal treatment under a controlled flow of $100 \%$ Ar gas. From the TG-DSC curves (Figure 7), the thermal decomposition of $\mathrm{CuS}$ can be divided into three major steps based on the DSC endotherm observed. The first decomposition step is identified in the temperature range of $38.0-165.0^{\circ} \mathrm{C}$ in which a shallow broad DSC endotherm is detected. This event is attributed to desorption of physisorbed water from $\mathrm{CuS}$ crystal as the mass-to-charge ratio $(\mathrm{m} / \mathrm{z})$ of 18 was evidenced from the MS signal. The second decomposition step is found in the temperature range of $217.0-$ $348.0^{\circ} \mathrm{C}$ in which a well-defined DSC endotherm is associated. This event can be related well to desorption of crystallization water as mass-to-charge ratio $(\mathrm{m} / \mathrm{z})$ of
18 was again evidenced from the MS signal. The third decomposition step is identified in the temperature range of $345.0-470.0^{\circ} \mathrm{C}$ in which a huge mass loss of the sample $(\approx 12.0 \%)$ as well as the sharp DSC endotherm is observed. Since no significant MS signal is detected, an endothermic event that involves the crystallographic changes from $\mathrm{CuS}$ phase to other $\mathrm{Cu}_{\mathrm{x}} \mathrm{S}$ phases is deduced. From the analysis, it is obvious that the as-formed $\mathrm{CuS}$ phase at $25.0^{\circ} \mathrm{C}$ will not be affected if reaction temperature is maintained below $300.0^{\circ} \mathrm{C}$. Furthermore, the synthesis conducted at $175^{\circ} \mathrm{C}$ also discloses that the microstructure of $\mathrm{CuS}$ hexagonal plates (Figure 6) remains as no obvious change in the morphology can be detected at this temperature. Thus, these results strongly suggest that the $\mathrm{CuS}$ hexagonal phase is retained as a single phase product if the decomposition
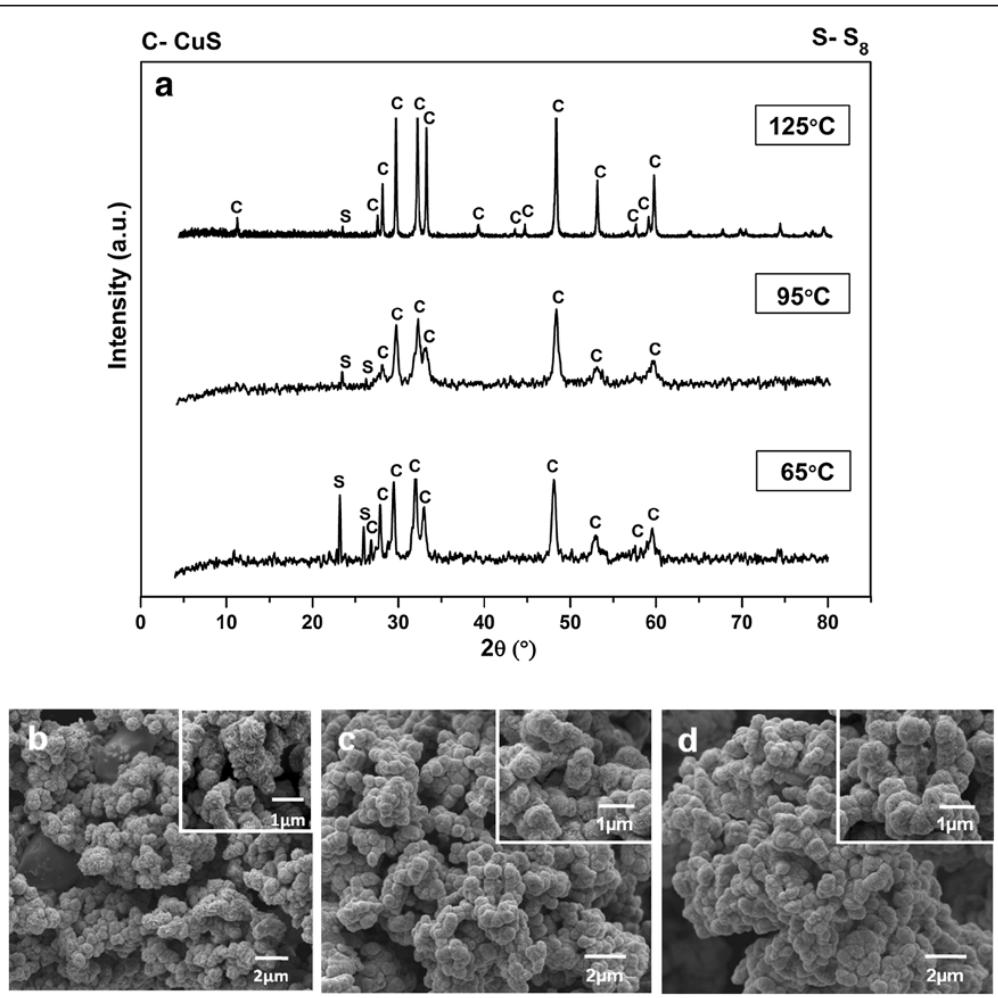

Figure 5 Products prepared at different reaction temperatures. Powder XRD patterns (a), FESEM images of products synthesized with $\mathrm{Cu}^{2+}: \mathrm{S}_{2} \mathrm{O}_{3}{ }^{2-}$ mole ratio of $1: 2$ for 12 hours at $65^{\circ} \mathrm{C}(\mathbf{b}), 95^{\circ} \mathrm{C}(\mathbf{c})$ and $125^{\circ} \mathrm{C}(\mathbf{d})$. 


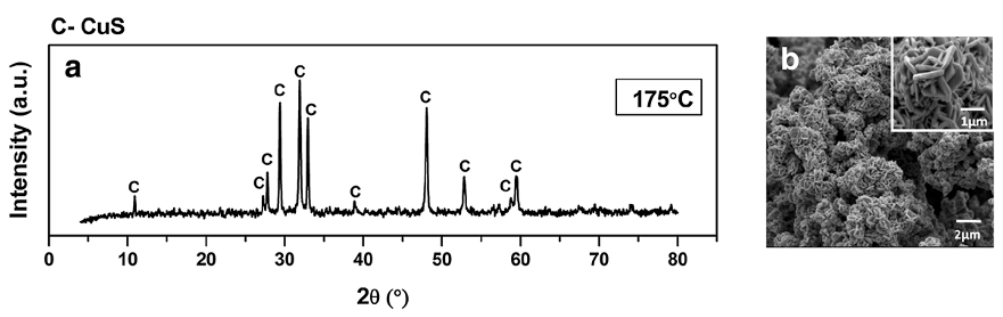

Figure 6 Product prepared at $175^{\circ} \mathrm{C}$. Powder XRD pattern (a) and FESEM images (b) of product synthesized at $175^{\circ} \mathrm{C}$ with $\mathrm{Cu}^{2+}: \mathrm{S}_{2} \mathrm{O}_{3}{ }^{2-} \mathrm{mole}$ ratio of 1: 2 for 12 hours.

of $\mathrm{S}_{8}$ ring impurity is performed in the range of $155.0-$ $300.0^{\circ} \mathrm{C}$. Therefore, the highlighted observations have shown that reaction temperature plays an important role in controlling the phase purity, crystal phase as well as morphology of the final product in the hydrothermal synthesis developed.

\section{Role of $\mathrm{Cu}^{2+}: \mathrm{S}_{2} \mathrm{O}_{3}^{2-}$ mole ratio in hydrothermal synthesis}

It has been identified previously that the variation of synthesis temperature is vital in directing the final crystal phase and morphology of the product. It is also found that pure $\mathrm{CuS}$ hexagonal phase can only be achieved if the synthesis is performed at $\mathrm{Cu}^{2+}: \mathrm{S}_{2} \mathrm{O}_{3}{ }^{2-}$ mole ratio of $1: 2$ under the reaction temperature of $155.0^{\circ} \mathrm{C}$. In this section, we further investigated the role of $\mathrm{Cu}^{2+}: \mathrm{S}_{2} \mathrm{O}_{3}{ }^{2-}$ mole ratio in the formation of copper sulphide via the variation of $\mathrm{Cu}^{2+}$ : $\mathrm{S}_{2} \mathrm{O}_{3}{ }^{2-}$ mole ratio under the typical synthesis condition. The powder XRD patterns of the products formed at $\mathrm{Cu}^{2+}$ : $\mathrm{S}_{2} \mathrm{O}_{3}{ }^{2-}$ mole ratio of $1: 1$ and $1: 1.5$ are displayed in Figure 8a; while the powder XRD patterns of the powder produced at $\mathrm{Cu}^{2+}: \mathrm{S}_{2} \mathrm{O}_{3}{ }^{2-}$ mole ratio of 1: 2.5, 1: 3 and 1: 5 are depicted in Figure 9 a.

In general, sharp and narrow peaks are observed from all the diffractograms signifying the formation of highly

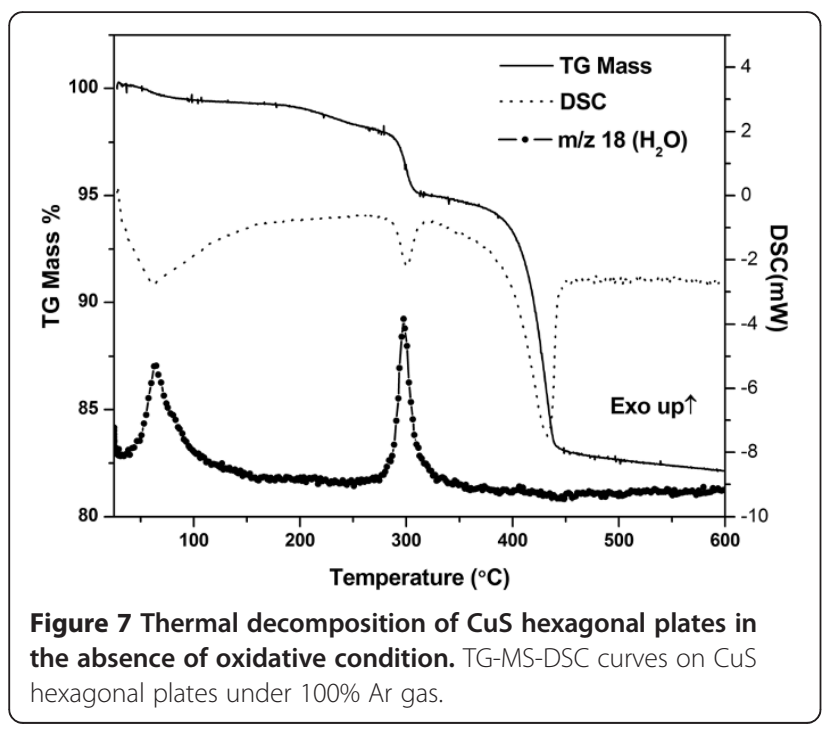

crystalline compounds. For the synthesis performed at $\mathrm{Cu}^{2+}: \mathrm{S}_{2} \mathrm{O}_{3}{ }^{2-}$ mole ratio of 1: 1 . However, phase pure natrochalcite $\left[\mathrm{NaCu}_{2}\left(\mathrm{SO}_{4}\right)\left(\mathrm{H}_{2} \mathrm{O}\right)\right]$ product with irregular plate-like morphology is detected (Figure $8 \mathrm{~b}$ ). For the synthesis performed at $\mathrm{Cu}^{2+}: \mathrm{S}_{2} \mathrm{O}_{3}{ }^{2-}$ mole ratio of $1: 1.5$, the diffraction peak of $\mathrm{CuS}$ phase is again not detected. Nevertheless, phase pure digenite $\left(\mathrm{Cu}_{9} \mathrm{~S}_{5}\right)$ with irregular platelet-like morphology is in fact identified (Figure 8c). For the synthesis conducted at $\mathrm{Cu}^{2+}: \mathrm{S}_{2} \mathrm{O}_{3}{ }^{2-}$ mole ration of 1: 2.5, 1: 3 and 1: 5 , both mixed phases of $\mathrm{CuS}$ and $\mathrm{S}_{8}$ are identified from their powder XRD patterns. In comparison of the products formed at $\mathrm{Cu}^{2+}: \mathrm{S}_{2} \mathrm{O}_{3}{ }^{2-}$ mole ration of 1: 2.5, 1: 3 and 1: 5, more intense crystalline $S_{8}$ peaks are detected from the XRD patterns when higher $\mathrm{Cu}^{2+}: \mathrm{S}_{2} \mathrm{O}_{3}{ }^{2-}$ mole ratio was applied which indicates that higher amount of $S_{8}$ is present in the system. From the FESEM images (Figure 9b-c), it is amazed to notice that the products obtained at $\mathrm{Cu}^{2+}: \mathrm{S}_{2} \mathrm{O}_{3}{ }^{2-}$ mole ration of 1 : 2.5 and 1: 3 show crystalline hexagonal plate morphology although certain degree of $\mathrm{S}_{8}$ impurity was detected in the system. Nevertheless, the crystalline hexagonal plate morphology is found to be reduced significantly when $\mathrm{Cu}^{2+}: \mathrm{S}_{2} \mathrm{O}_{3}{ }^{2-}$ mole ratio was increased to $1: 5$ in which a substantial amount of solid mass can be observed from the FESEM image depicted in Figure 9d. From the appealing observations found in this investigation, it can be deduced that the extensive growth of crystalline $\mathrm{S}_{8}$ has an inhibiting effect towards the growth of $\mathrm{CuS}$ hexagonal plate architecture. The amplified growth of crystalline $\mathrm{S}_{8}$ in the synthesis of $\mathrm{Cu}^{2+}: \mathrm{S}_{2} \mathrm{O}_{3}{ }^{2-}$ mole ratio of 1: 5 has dominated the development of $\mathrm{CuS}$ hexagonal plates. Consequently, this has led to the coverage of crystalline $\mathrm{S}_{8}$ on CuS surface which resulted in a more coarsened morphology detected at $\mathrm{Cu}^{2+}: \mathrm{S}_{2} \mathrm{O}_{3}{ }^{2-}$ mole ratio of $1: 5$.

In this work, efforts have been put to correlate the experimental observations with the chemical reactions occurred. Pryor et. al. reported that $\mathrm{S}_{2} \mathrm{O}_{3}{ }^{2-}$ undergoes irreversible disproportionation in water to produce $\mathrm{HS}^{-}$, $\mathrm{SO}_{4}{ }^{2-}$ and a small amount of $\mathrm{S}_{8}$ species as indicated in equation (1) [39].

$$
\mathrm{S}_{2} \mathrm{O}_{3}{ }^{2-}+\mathrm{H}_{2} \mathrm{O} \rightarrow \mathrm{SO}_{4}{ }^{2-}+\mathrm{HS}^{-}+H^{+}
$$




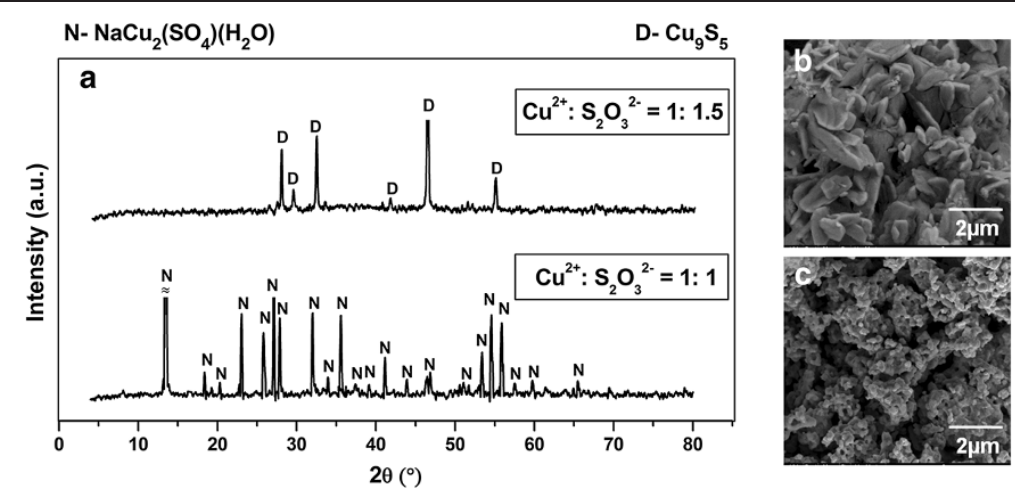

Figure 8 Products prepared at different $\mathrm{Cu}^{2+}: \mathrm{S}_{2} \mathrm{O}_{3}^{2-}$ mole ratio. Powder XRD patterns (a), FESEM images of products synthesized at $155^{\circ} \mathrm{C}$ for 12 hours with $\mathrm{Cu}^{2+}: \mathbf{S}_{2} \mathbf{O}_{3}^{2-}$ mole ratio of $1: 1(\mathbf{b})$ and $1: 1.5(\mathbf{c})$.

On the other hand, an examination of the $\mathrm{S}_{8}$ species in basic solution revealed that $\mathrm{S}_{2} \mathrm{O}_{3}{ }^{2-}$, $\mathrm{HS}^{-}$and $\mathrm{SO}_{4}{ }^{2-}$ species can be produced as shown in the following $[40,41]$ :

$$
\begin{aligned}
& S_{8}+8 \mathrm{OH}^{-} \leftrightarrow 2 \mathrm{~S}_{2} \mathrm{O}_{3}{ }^{2-}+4 \mathrm{HS}^{-}+2 \mathrm{H}_{2} \mathrm{O} \\
& S_{8}+10 \mathrm{OH}^{-} \leftrightarrow 2 \mathrm{SO}_{4}{ }^{2-}+6 \mathrm{HS}^{-}+2 \mathrm{H}_{2} \mathrm{O}
\end{aligned}
$$

The reactions shown in equations (2) and (3) are reversible due to the presence of large amount of $\mathrm{HS}^{-}$and
$\mathrm{SO}_{4}{ }^{2-}$ species in the solution. Thus, the overall reaction which led to the formation of $\mathrm{S}_{8}$ species can be summarized as below:

$$
\mathrm{S}_{2} \mathrm{O}_{3}{ }^{2-}+\mathrm{SO}_{4}{ }^{2-}+5 \mathrm{HS}^{-}+2 \mathrm{H}_{2} \mathrm{O} \leftrightarrow \mathrm{S}_{8}+9 \mathrm{OH}^{-}
$$

As indicated above, the resulting reaction equilibrium is shifted towards the formation of $\mathrm{S}_{8}$ species. Its presence has been evidenced by powder XRD technique at $\mathrm{Cu}^{2+}$ :
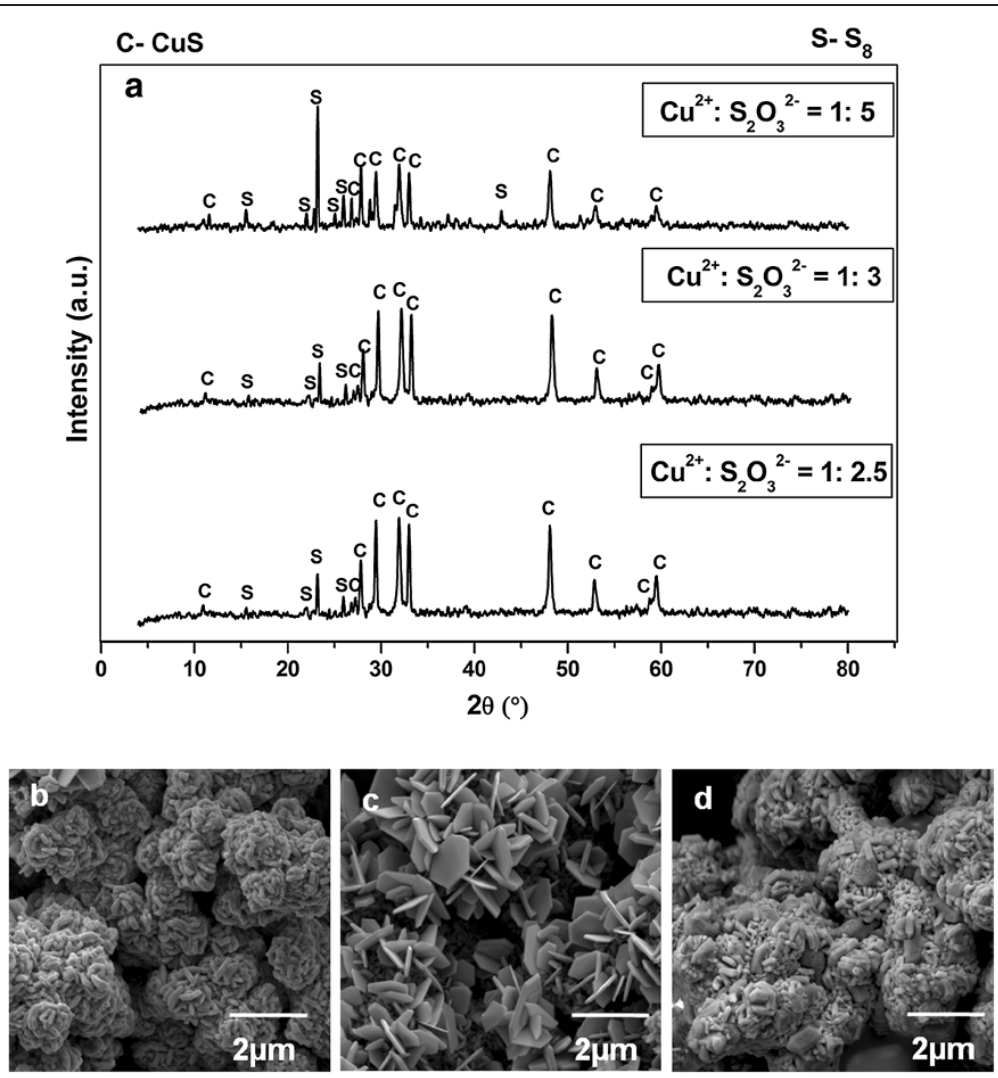

Figure 9 Products prepared at different $\mathrm{Cu}^{2+}: \mathrm{S}_{2} \mathrm{O}_{3}^{2-}$ mole ratio. Powder XRD patterns (a), FESEM images of products synthesized at $155^{\circ} \mathrm{C}$ for 12 hours with $\mathrm{Cu}^{2+}: \mathrm{S}_{2} \mathrm{O}_{3}{ }^{2-}$ mole ratio of $1: 2.5$ (b), $1: 3$ (c) and 1:5 (d). 
$\mathrm{S}_{2} \mathrm{O}_{3}{ }^{2-}$ mole ratio of $1: 2.5,1: 3$ and $1: 5$ during the hydrothermal treatment.

For reaction conducted at $\mathrm{Cu}^{2+}: \mathrm{S}_{2} \mathrm{O}_{3}{ }^{2-}$ mole ratio of 1 : 1 , the formation of $\mathrm{NaCu}_{2}\left(\mathrm{SO}_{4}\right)\left(\mathrm{H}_{2} \mathrm{O}\right)$ with irregular platelike morphology has been detected. This observation can be explained via the presence of large amount of $\mathrm{SO}_{4}{ }^{2-}$ species in the reaction. From equation (4), 5 mole of $\mathrm{HS}^{-}$ reacted with 1 mole of $\mathrm{SO}_{4}{ }^{2-}$ in the formation of $\mathrm{S}_{8}$ species. The consumption of $\mathrm{HS}^{-}$is 5 times higher than $\mathrm{SO}_{4}{ }^{2-}$ in the $\mathrm{S}_{8}$ species formation pathway. In addition, it is well known that $\mathrm{HS}^{-}$species is reactive and is rapidly oxidized by dissolved oxygen in water to form $\mathrm{SO}_{4}{ }^{2-}$ species. Therefore, it is expected that the formation of $\mathrm{NaCu}_{2}\left(\mathrm{SO}_{4}\right)\left(\mathrm{H}_{2} \mathrm{O}\right)$ is more feasible in relative to $\mathrm{CuS}$ with the presence of excessive amount of $\mathrm{SO}_{4}{ }^{2-}$ species in the system. For synthesis carried out at $\mathrm{Cu}^{2+}: \mathrm{S}_{2} \mathrm{O}_{3}{ }^{2-}$ mole ratio of $1: 1.5$, digenite $\left(\mathrm{Cu}_{9} \mathrm{~S}_{5}\right)$ with platelet-like morphology was identified. Its formation can be closely related to the slight increased of active $\mathrm{HS}^{-}$present in the solution. An increase in $\mathrm{Cu}^{2+}: \mathrm{S}_{2} \mathrm{O}_{3}{ }^{2-}$ mole ratio undeniably elevates the quantity of active $\mathrm{HS}^{-}$. It is believed that the increased amount of $\mathrm{HS}^{-}$used to precipitate digenite $\left(\mathrm{Cu}_{9} \mathrm{~S}_{5}\right)$ has outpaced the formation of crystalline $\mathrm{S}_{8}$ but it is still insufficient in precipitating $\mathrm{CuS}$. Thus, this has eventually led to the formation of metastable state copper sulphide, namely $\mathrm{Cu}_{9} \mathrm{~S}_{5}$ when $\mathrm{Cu}^{2+}: \mathrm{S}_{2} \mathrm{O}_{3}{ }^{2-}$ mole ratio of 1: 1.5 was applied in this reaction.

For synthesis conducted at $\mathrm{Cu}^{2+}: \mathrm{S}_{2} \mathrm{O}_{3}{ }^{2-}$ mole ratio of 1: 2.5 and 1: 3 , mixture of $\mathrm{CuS}$ and $\mathrm{S}_{8}$ phases with crystalline hexagonal plate morphology has been observed. However, when $\mathrm{Cu}^{2+}: \mathrm{S}_{2} \mathrm{O}_{3}{ }^{2-}$ mole ratio was raised to $1: 5$, an increase amount of $\mathrm{S}_{8}$ phase in relative to $\mathrm{CuS}$ phase is detected. From equation (1), it is obvious that an increase amount of $\mathrm{S}_{2} \mathrm{O}_{3}{ }^{2-}$ used will amplify the contribution of $\mathrm{SO}_{4}{ }^{2-}$ and $\mathrm{HS}^{-}$species. Subsequently, a greater conversion of $\mathrm{S}_{2} \mathrm{O}_{3}{ }^{2-}$ and $\mathrm{SO}_{4}{ }^{2-}$ into $\mathrm{S}_{8}$ will be expected based on disproportionation reaction shown in equation (4). The reaction pathway proposed is in good agreement with the product formed because the additional $S_{8}$ phase identified is significantly increased in the powder synthesized at $\mathrm{Cu}^{2+}: \mathrm{S}_{2} \mathrm{O}_{3}{ }^{2-}$ mole ratio of $1: 3$ and 1: 5 . Therefore, it is considerably important to employ an appropriate $\mathrm{Cu}^{2+}: \mathrm{S}_{2} \mathrm{O}_{3}{ }^{2-}$ mole ratio for the growth of phase pure $\mathrm{CuS}$ hexagonal plates in the reaction.

\section{Role of reaction time in hydrothermal synthesis}

For the reaction time studies, investigations were further carried out at synthesis time of 1,3 and 8 hours to determine the minimum time required to achieve phase pure $\mathrm{CuS}$ formation under $\mathrm{Cu}^{2+}: \mathrm{S}_{2} \mathrm{O}_{3}{ }^{2-}$ mole ratio of
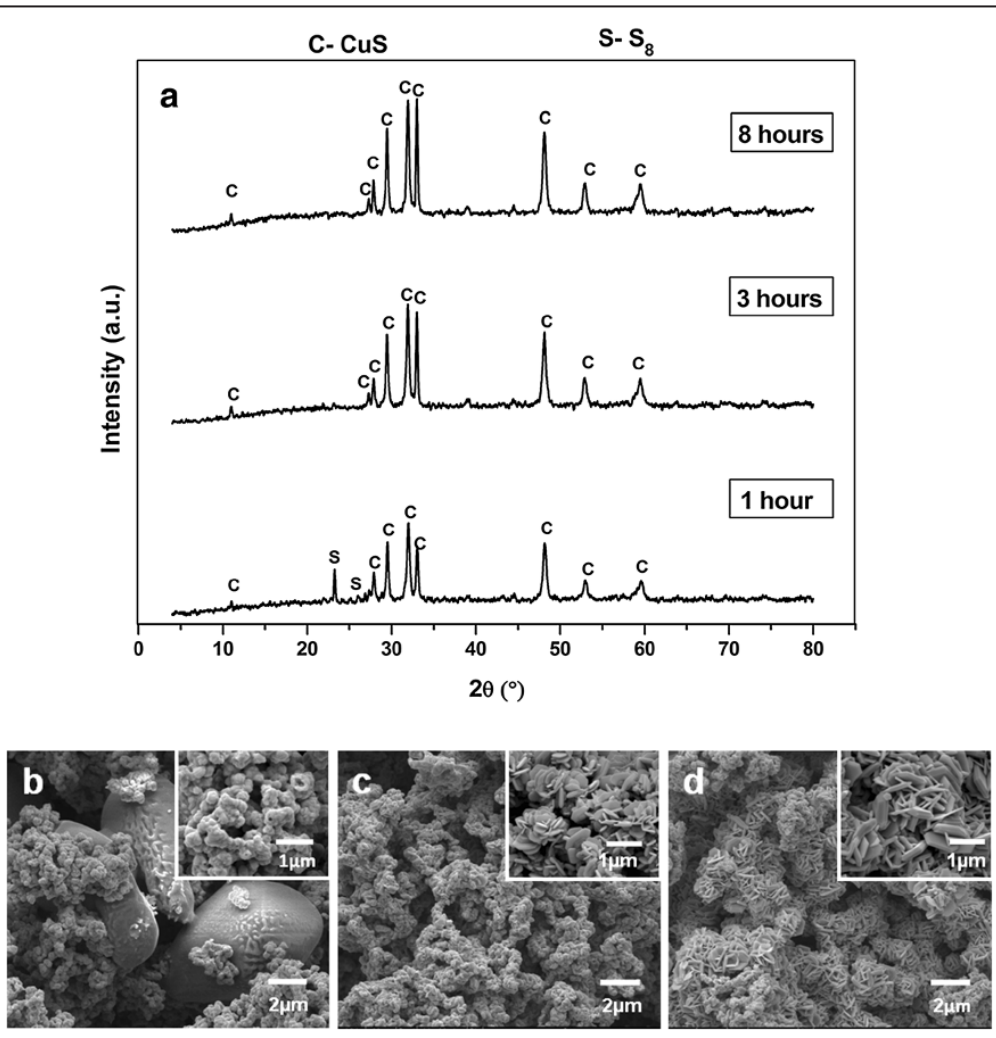

Figure 10 Products prepared at different reaction time. Powder XRD patterns (a), FESEM images of products synthesized with $\mathrm{Cu}^{2+}: \mathrm{S}_{2} \mathrm{O}_{3}{ }^{2-}$ mole ratio of $1: 2$ at $155^{\circ} \mathrm{C}$ for 1 hour (b), 3 hours (c) and 8 hours (d). 
1: 2 at $155.0^{\circ} \mathrm{C}$. The powder XRD patterns and morphology of the products formed at different synthesis time were depicted in Figure 10a-d respectively. At reaction time of 1 hour, phase mixtures of covellite and cyclooctasulphur were found in its powder XRD pattern. This observation is coupled with the absence of hexagonal shaped particles (Figure 10b) as well as the appearance of big solid mass detected from FESEM analysis. This finding strongly suggests that reaction time of 1 hour is insufficient to promote the formation of highly crystalline $\mathrm{CuS}$ hexagonal plates and complete decomposition of cyclooctasulphur under the hydrothermal synthesis.

As the reaction time was prolonged to 3 and 8 hours, it can be observed that only covellite phase is remained while cyclooctasulphur has been diminished entirely from the powder XRD patterns. This observation is associated with the single morphology of hexagonal shaped particles identified from FESEM analysis. These results again indicate that the decomposition of cyclooctasulphur occurs during the hydrothermal treatment at $155^{\circ} \mathrm{C}$ in which reaction time of 3 hours is enough to eliminate this impurity completely. Further analysis of the powder XRD pattern for the pure phase $\mathrm{CuS}$ synthesized has been carried out using Scherrer Formula (1918) [42]:

$$
D=k \lambda / \beta \cos \theta
$$

where $D$ is the average crystallite size, $k$ is the Scherrer constant (0.94), $\lambda$ is the X-ray wavelength $(0.15406 \mathrm{~nm}$ for $\left.\mathrm{CuK}_{\alpha}\right), \beta$ is the angular linewidth of half maximum intensity (FWHM) in radians unit, $\theta$ is the Bragg angle corresponding to the maximum of the diffraction peak in degrees unit. The average crystallite size of the asformed $\mathrm{CuS}$ phase at reaction time of 3, 8 and typically 12 hours were estimated as $(31.49 \pm 1.44),(34.80 \pm 1.59)$, and $(44.94 \pm 2.37) \mathrm{nm}$ respectively. This observation implies that the process of crystallite growth is in favour when synthesis time is lengthened. In fact, the trend of increasing crystallite size with time is also found when comparing the powder XRD patterns of these three products. The diffraction peaks of the respective compounds have become sharper with time, indicating that more crystalline material with larger size was obtained when reaction time was prolonged.

\section{Formation mechanism of CuS hexagonal plates}

From the studies above, it is identified that the formation of $\mathrm{CuS}$ crystal phase can be obtained at almost all synthesis conditions studied (variation of $\mathrm{Cu}^{2+}: \mathrm{S}_{2} \mathrm{O}_{3}{ }^{2-}$ mole ratio of 1: 2 to $1: 5$, reaction temperature of 25 to $155^{\circ} \mathrm{C}$ and reaction time of 1 to 12 hours). These results indicate that the $\mathrm{CuS}$ crystal phase is a thermodynamically stable compound in which under a suitable
$\mathrm{Cu}^{2+}: \mathrm{S}_{2} \mathrm{O}_{3}{ }^{2-}$ mole ratio, its formation is feasible regardless of the synthesis temperature and reaction time applied. In the reaction between $\mathrm{Cu}\left(\mathrm{NO}_{3}\right)_{2}$ and $\mathrm{Na}_{2} \mathrm{~S}_{2} \mathrm{O}_{3}$, it is reasonable to consider that the main $\mathrm{CuS}$ formation pathway proceeds firstly via the relatively stable $\left[\mathrm{Cu}\left(\mathrm{S}_{2} \mathrm{O}_{3}\right)\left(\mathrm{H}_{2} \mathrm{O}\right)_{2}\right]$ and $\left[\mathrm{Cu}\left(\mathrm{S}_{2} \mathrm{O}_{3}\right)_{2}\right]^{2-}$ complexes formation $[21,43]$.

$$
\begin{aligned}
& \mathrm{Cu}^{2+}+2 \mathrm{~S}_{2} \mathrm{O}_{3}{ }^{2-} \rightarrow\left[\mathrm{Cu}\left(\mathrm{S}_{2} \mathrm{O}_{3}\right)_{2}\right]^{2-} \\
& \mathrm{Cu}^{2+}+\mathrm{S}_{2} \mathrm{O}_{3}{ }^{2-}+2 \mathrm{H}_{2} \mathrm{O} \rightarrow\left[\mathrm{Cu}\left(\mathrm{S}_{2} \mathrm{O}_{3}\right)_{2}\left(\mathrm{H}_{2} \mathrm{O}\right)_{2}\right]
\end{aligned}
$$

A subsequent disproportionation reaction takes place in the complexes mentioned above resulting in a complete dissociation of $\mathrm{Cu}^{2+}, \mathrm{SO}_{4}^{2-}$ and $\mathrm{S}^{2-}$ in the next step.

$$
\begin{aligned}
{\left[\mathrm{Cu}\left(\mathrm{S}_{2} \mathrm{O}_{3}\right)_{2}\right]^{2-}+\mathrm{H}_{2} \mathrm{O} \rightarrow } & \mathrm{Cu}^{2+}+\mathrm{SO}_{4}{ }^{2-}+\mathrm{S}^{2-} \\
& +2 \mathrm{H}^{+} \\
{\left[\mathrm{Cu}\left(\mathrm{S}_{2} \mathrm{O}_{3}\right)_{2}\left(\mathrm{H}_{2} \mathrm{O}\right)_{2}\right] \rightarrow } & \mathrm{Cu}^{2+}+\mathrm{SO}_{4}{ }^{2-}+\mathrm{S}^{2-} \\
+ & 2 \mathrm{H}^{+}+\mathrm{H}_{2} \mathrm{O}
\end{aligned}
$$

The key step of $\mathrm{CuS}$ formation is suggested to be an in situ reduction of $\mathrm{Cu}^{2+}$ to $\mathrm{Cu}^{+}$ion and oxidation of $\mathrm{S}^{2-}$ to $\mathrm{S}^{-}$and $\mathrm{S}_{2}^{2-}$ species when bare $\mathrm{S}^{2-}$ is reacting with $\mathrm{Cu}^{2+}$ ion.

$$
\begin{aligned}
3 \mathrm{Cu}^{2+}+3 S^{2-} & \rightarrow 3 \mathrm{Cu}^{+}+S^{-}+\left(S_{2}\right)^{2-} \\
& \equiv\left(\mathrm{Cu}^{+}\right)_{3}\left(S^{-}\right)\left(S_{2}\right)^{2-} \downarrow
\end{aligned}
$$

It can be observed that the final reaction shown is not a simple balanced charged reaction that resulted from $\mathrm{Cu}^{2+}$ and $\mathrm{S}^{2-}$. In fact, the crystal structure of covellite $(\mathrm{CuS})$ has been evidenced by single crystal experiment in which it is composed of $(\mathrm{Cu})_{3}\left(\mathrm{~S}_{(}\left(\mathrm{S}_{2}\right)\right.$ [44]. The assignment of formal charges of $\mathrm{Cu}^{+}, \mathrm{S}^{-}$and $\mathrm{S}_{2}{ }^{2-}$ was actually based on the interpretation from X-Ray photoelectron spectroscopy (XPS) [45]. In addition, the presence of $\mathrm{Cu}(\mathrm{I})$ instead of $\mathrm{Cu}(\mathrm{II})$ in the crystal lattice was also proven from X-Ray photoelectron (XPS) and X-ray absorption spectroscopic (NEXAFS) studies $[33,46]$. Taking the monovalency of all copper atoms into account, covellite should not be regarded as $\mathrm{Cu}$ (II) sulphide [33]. Therefore, the mechanism deduction which involves the formation of covellite should be based on its molecular formula, $\left(\mathrm{Cu}^{+}\right)_{3}\left(\mathrm{~S}^{-}\right)\left(\mathrm{S}_{2}\right)^{2-}$ rather than its empirical formula, CuS. The key reaction should consist of a series of redox reactions which build up the core crystal unit of $\mathrm{Cu}^{+}, \mathrm{S}^{-}$and $\left(\mathrm{S}_{2}\right)^{2-}$ in the final crystal system.

For any crystallite formation, it is renowned that both of the nucleation and growth process play important roles in determining the morphology of the product formed. For the case of $\mathrm{CuS}$ hexagonal plate-like architecture, it is believed that its formation is closely related to the crystallographic phase of the seed formed during the nucleation process and its surface selective crystallization in the growth process. The formation of platelet-like $\mathrm{CuS}$ seed has been expected in the reaction 
due to the intrinsic anisotropic characteristics of the $\mathrm{CuS}$ hexagonal crystal structure [20,22]. In the subsequent growth stage, the platelet-like seed will grow in a different rate along the planes due to the different surface energy distribution. It was reported that hexagonal metal with a c/a ratio greater than 1.63, surface energy at $\{101\}$ and $\{100\}$ surfaces will be 1.5 times greater compared to $\{001\}$ facets [47]. Similarly, the c/a ratio of $\mathrm{CuS}$ is determined to be 4.31 in which an even higher surface energy will be expected at $\{101\}$ and $\{100\}$ surfaces [22]. This has induced a relatively fast crystal growth at these facets and resulting in a hexagonal shape particle instead of rod-like particle being observed in the powder [48]. Finally, the formation of stacked-like $\mathrm{CuS}$ hexagonal plate morphology can be considered as a typical Ostwald ripening process. Owing to the higher surface energy of small seed crystal, its dissolution and re-deposition onto the larger hexagonal platelet surfaces at different orientation arise during the reaction. The extensive growth of the small seed crystal at bigger dimension of hexagonal plate has resulted in the perpendicular intersection of the platelet-like structure. This process has eventually led to the formation of stackedlike $\mathrm{CuS}$ hexagonal plate morphology as depicted in the final powder obtained.

\section{Conclusions}

Via the optimization of reaction parameters in hydrothermal reactions between copper (II) nitrate and sodium thiosulphate without appending any assistant agent, it is found that $\mathrm{CuS}$ hexagonal plates can be successfully synthesized at $\mathrm{Cu}^{2+}: \mathrm{S}_{2} \mathrm{O}_{3}{ }^{2-}$ mole ratio of 1: 2 under reaction temperature of $155^{\circ} \mathrm{C}$ for 12 hours. FESEM and TEM examinations confirmed that the $\mathrm{CuS}$ hexagonal plates architecture are assembled, stacked and interlaced perpendicular to each other with an mean edge length of $1 \mu \mathrm{m}$ and thickness of $100 \mathrm{~nm}$. The reactions between copper (II) nitrate and sodium thiosulphate at different synthesis conditions produce a wide range of crystal phases in addition to the covellite $(\mathrm{CuS})$ phase in which a systematic approach is required to decompose the impurities. It is identified that both the reaction temperature and time are important parameters in decomposing the impurities present. Whilst, $\mathrm{Cu}^{2+}$ : $\mathrm{S}_{2} \mathrm{O}_{3}{ }^{2-}$ mole ratio is playing a vital role in controlling the amount of cyclooctasulphur $\left(\mathrm{S}_{8}\right)$ present in the final powder obtained. A possible formation mechanism of $\mathrm{CuS}$ hexagonal plates based on the presence of $\mathrm{Cu}$ (I) instead of $\mathrm{Cu}$ (II) species in the crystal structure of covellite $(\mathrm{CuS})$ was also proposed. This facile and mild hydrothermal batch route developed provides a promising new methodology in studying the reaction chemistry of aqueous solution phase reactants as well as synthesizing phase pure $\mathrm{CuS}$ hexagonal plates.

\section{Experimental}

\section{Synthesis and formation studies of CuS hexagonal plates}

All reagents used in this study are of analytical grade, obtained from commercial market and were used without further purification. Sodium thiosulphate pentahydrate $\left(\mathrm{Na}_{2} \mathrm{~S}_{2} \mathrm{O}_{3} .5 \mathrm{H}_{2} \mathrm{O}\right.$, Merck) was selected as the sulphur source while copper nitrate pentasemihydrate $\left(\mathrm{Cu}\left(\mathrm{NO}_{3}\right)\right.$ ${ }_{2} .2 \frac{1}{2} \mathrm{H}_{2} \mathrm{O}$, Riedel de Häen) was used as the copper source. In a typical procedure, $\mathrm{CuS}$ was synthesized by reacting $0.025 \mathrm{~mol}$ of copper nitrate with $0.05 \mathrm{~mol}$ of sodium thiosulphate $\left(\mathrm{Cu}^{2+}: \mathrm{S}_{2} \mathrm{O}_{3}{ }^{2-}\right.$ mole ratio $\left.=1: 2.0\right)$ in $40.00 \mathrm{ml}$ deionized water. The solutions were mixed thoroughly under constant stirring for 15 minutes; homogeneous slurry was formed, which was then transferred into a sealed $100 \mathrm{ml}$ Teflon-lined stainless steel tube and put into a custom-made rotating furnace. The rotating furnace was maintained at $155.0^{\circ} \mathrm{C}$ for 12 hours. To measure the synthesis temperature during the reaction, a thermocouple was placed inside the furnace every hour through an injection port without opening the furnace. After 12 hours, the Teflon-lined stainless steel tube was allowed to cool down naturally at ambient temperature. The obtained product was washed with batches of deionized water until the final filtrate showed conductivity of less than $10 \mu \mathrm{S} / \mathrm{cm}$. The collected product was then dried overnight at ambient temperature in a vacuum desiccator which consists of silica gels as drying agent. After that, the dried sample was purged with purified nitrogen gas for 3 minutes prior storage to prevent the oxidation of the sample [49]. In order to study the role of $\mathrm{Cu}^{2+}: \mathrm{S}_{2} \mathrm{O}_{3}{ }^{2-}$ mole ratio, the synthesis was varied in the range of $\mathrm{Cu}^{2+}: \mathrm{S}_{2} \mathrm{O}_{3}{ }^{2-}$ mole ratio = 1: $1-1: 5$ at $155^{\circ} \mathrm{C}$ for 12 hours where the number of mole of copper nitrate employed was fixed at $0.025 \mathrm{~mol}$. Meanwhile, the role of synthesis temperature was investigated by controlling the furnace temperature at 25,65 , 95,125 and $175^{\circ} \mathrm{C}$ by keeping the other synthesis parameters at constant. The studies on reaction time parameter were examined at 1,3 and 8 hours with $\mathrm{Cu}^{2+}: \mathrm{S}_{2} \mathrm{O}_{3}{ }^{2-}$ mole ratio and synthesis temperature fixed at $1: 2$ and $155^{\circ} \mathrm{C}$.

\section{Characterization and analysis of solid samples}

The crystalline phase and purity of the synthesized products were identified by powder X-ray Diffraction (XRD), using a Bruker X-ray Diffraction Model D-8 equipped with a $\mathrm{Cu} K \alpha$ monochromatized radiation source $(\lambda=1.5406 \AA)$ in the range of $4^{\circ} \leq 2 \theta \leq 80^{\circ}$. Field Emission Scanning Electron Microscopy (FESEM) images and Energy Dispersive X-ray (EDX) were done by using FEI Quanta 200 FESEM. The bulk elemental composition of the material was determined by X-ray Fluorescence (XRF) spectrometer by Bruker (S4-Explorer). TEM and HRTEM images were recorded from a FEI Cs-corrected Titan 80-300 microscope operated at $300 \mathrm{kV}$. The TG/ DSC results were 
acquired using NETZSCH STA 449C device coupled with Quadrupole Mass Spectrometer (Thermostar, Balzers). A heating rate of $5^{\circ} \mathrm{C} \mathrm{min}{ }^{-1}$ with mass flow of $30 \mathrm{~cm}^{3} \mathrm{~min}^{-1}$ was applied in investigating the thermal property of the product.

\section{Competing interests}

The authors declare that they have no competing interests.

\section{Authors' contributions}

YLA has carried out conceptual studies on the formation mechanism of CuS and participated in the manuscript preparation. PLY carried out the synthesis, data analysis on the compounds formed, and helped in the manuscript preparation. XH involved in HRTEM data acquisition and interpretation, as well as manuscript revision. SBAH provided idea and participated in the design of copper sulphide. All authors read and approved the final manuscript.

\section{Acknowledgements}

This work was financially supported by University of Malaya under University Malaya Research Grant (RG 022-09AET) and Postgraduate Research Fund (PS 376-2010B and PS 377-2010B).

\section{Author details}

'COMBICAT Laboratory, Nanotechnology \& Catalysis Research Centre (NANOCAT), University of Malaya, Kuala Lumpur 50603, Malaysia. ${ }^{2}$ Chemistry Department, Faculty of Science, University of Malaya, Kuala Lumpur 50603, Malaysia. ${ }^{3}$ Key Laboratory of Photochemical Conversion and Optoelectronic Materials, Technical Institute of Physics and Chemistry, Chinese Academy of Sciences, Beijing 100190, China.

Received: 7 February 2013 Accepted: 8 April 2013 Published: 10 April 2013

\section{References}

1. Wang YY, Li Q, Nie M, Li XL, Li Y, Zhong XL: High-yield room temperature route to copper sulfide hollow nanospheres and their electrochemical properties. Nanotechnology 2011, 22:305401-305406.

2. Li F, Wu JF, Qin QH, Li Z, Huang XT: Controllable synthesis, optical and photocatalytic properties of CUS nanomaterials with hierarchical structures. Powder Technol 2010, 198:267-274.

3. Erokhina S, Erokhin V, Nicolini C, Sbrana F, Ricci D, di Zitti E: Microstructure origin of the conductivity differences in aggregated CuS films of different thickness. Langmuir 2003, 19:766-771.

4. Tan ZG, Zhu Q, Guo XZ, Zhang JF, Wu WY, Liu AP: Synthesis of flowershaped CUS microsphere superstructures by a solvothermal route and its photocatalytic properties. Acta Chim $\operatorname{Sin} 2011,69: 2812-2820$.

5. $\mathrm{Yu} \mathrm{XL}, \mathrm{An} \mathrm{XQ}$ : Controllable hydrothermal synthesis of $\mathrm{Cu}_{2} \mathrm{~S}$ nanowires on the copper substrate. Mater Lett 2010, 64:252-254.

6. Sagade AA, Sharma R: Copper sulphide $\left(\mathrm{Cu}_{\mathrm{x}} \mathrm{S}\right)$ as an ammonia gas sensor working at room temperature. Sensor Actuat B-Chem 2008, 133:135-143.

7. Reijnen L, Meester B, Goossens A, Schoonman J: Atomic layer deposition of $\mathrm{Cu}_{x} \mathrm{~S}$ for solar energy conversion. Chem Vapor Depos 2003, 9:15-20.

8. Chung JS, Sohn HJ: Electrochemical behaviors of $\mathrm{CuS}$ as a cathode material for lithium secondary batteries. J Power Sources 2002, 108:226-231.

9. Zhang P, Gao L: Copper sulfide flakes and nanodisks. J Mater Chem 2003, 13:2007-2010.

10. Singh KV, Martinez-Morales AA, Bozhilov KN, Ozkan M: A simple way of synthesizing single-crystalline semiconducting copper sulfide nanorods by using ultrasonication during template-assisted electrodeposition. Chem Mater 2007, 19:2446-2454.

11. Zhu T, Xia B, Zhou L, Wen Lou X: Arrays of ultrafine CuS nanoneedles supported on a CNT backbone for application in supercapacitors. J Mater Chem 2012, 22:7851-7855.

12. Roy P, Srivastava SK: Hydrothermal growth of CUS nanowires from $\mathrm{Cu}$ - dithiooxamide, a novel single-source precursor. Cryst Growth \& Des 2006, 6:1921-1926.

13. Lu Q, Gao F, Zhao D: One-step synthesis and assembly of copper sulfide nanoparticles to nanowires, nanotubes, and nanovesicles by a simple organic amine-assisted hydrothermal process. Nano Lett 2002, 2:725-728.
14. Wang Q, Li J-X, Li G-D, Cao X-J, Wang K-J, Chen J-S: Formation of CuS nanotube arrays from $\mathrm{CuCl}$ Nanorods through a gas-solid reaction route. J Cryst Growth 2007, 299:386-392.

15. Chen $Y-B$, Chen L, Wu L-M: Water-induced thermolytic formation of homogeneous core - shell CuS microspheres and their shape retention on desulfurization. Cryst Growth \& Des 2008, 8:2736-2740.

16. Zeng H, Rice PM, Wang SX, Sun S: Shape-controlled synthesis and shapeinduced texture of $\mathrm{MnFe}_{2} \mathrm{O}_{4}$ Nanoparticles. J Am Chem Soc 2004, 126:11458-11459.

17. Song Q, Zhang ZJ: Shape control and associated magnetic properties of spinel cobalt ferrite nanocrystals. J Am Chem Soc 2004, 126:6164-6168.

18. Cao YC: Synthesis of square gadolinium-oxide nanoplates. J Am Chem Soc 2004, 126:7456-7457.

19. Chen S, Carroll DL: Synthesis and characterization of truncated triangular silver nanoplates. Nano Lett 2002, 2:1003-1007.

20. Du W, Qian X, Ma X, Gong Q, Cao H, Yin J: Shape-controlled synthesis and self-assembly of hexagonal covellite (CuS) nanoplatelets. Chem Eur J 2007, 13:3241-3247.

21. Chu LM, Zhou BB, Mu HC, Sun YZ, Xu P: Mild hydrothermal synthesis of hexagonal CuS nanoplates. J Cryst Growth 2008, 310:5437-5440.

22. Liu Y, Qin D, Wang L, Cao Y: A facile solution route to CuS hexagonal nanoplatelets. Mater Chem Phys 2007, 102:201-206.

23. Basu M, Sinha AK, Pradhan M, Sarkar S, Negishi Y, Govind, Pal T: Evolution of hierarchical hexagonal stacked plates of CuS from liquid - liquid interface and its photocatalytic application for oxidative degradation of different dyes under indoor lighting. Environ Sci Technol 2010, 44:6313-6318.

24. Zhang $Y$, Wang $H$, Wang $B$, Yan $H$, Yoshimura M: Low-temperature hydrothermal synthesis of pure metastable $\gamma$-manganese sulfide (MnS) crystallites. J Cryst Growth 2002, 243:214-217.

25. Demazeau G: Solvothermal processes: a route to the stabilization of new materials. J Mater Chem 1999, 9:15-18.

26. Yang S, Zavalij PY, Stanley Whittingham M: Hydrothermal synthesis of lithium iron phosphate cathodes. Electrochem Commun 2001, 3:505-508.

27. Yoshimura M: Importance of soft solution processing for advanced inorganic materials. J Mater Res 1998, 13:796-802.

28. Chen J, Deng S, She J, Xu N, Zhang W, Wen X, Yang S: Effect of structural parameter on field emission properties of semiconducting copper sulphide nanowire films. J Appl Phys 2003, 93:1774-1777.

29. Brelle MC, Torres-Matinez CL, McNulty JC, Mehra RK, Zhang JZ: Synthesis and characterization of $\mathrm{Cu}_{\mathrm{x}} \mathrm{S}$ nanoparticles. Nature of the infrared band and charge-carrier dynamics. Pure Appl Chem 2000, 72:101-117.

30. Tsamouras D, Dalas E, Sakkopoulos S, Koutsoukos PG: Preparation and characterization of $\mathrm{Cu}(\mathrm{II}), \mathrm{Zn}(\mathrm{II})$ sulfides obtained by spontaneous precipitation in electrolyte solutions. Langmuir 1998, 14:5298-5304.

31. Gao J, Li Q, Zhao H, Li L, Liu C, Gong Q, Qi L: One-pot synthesis of uniform $\mathrm{Cu}_{2} \mathrm{O}$ and $\mathrm{CuS}$ hollow spheres and their optical limiting properties. Chem Mater 2008, 20:6263-6269.

32. Kore RH, Kulkarni JS, Haram SK: Effect of nonionic surfactants on the kinetics of disproportion of copper sulfide nanoparticles in the aqueous sols. Chem Mater 2001, 13:1789-1793.

33. Goh SW, Buckley AN, Lamb RN: Copper(II) sulfide? Miner. Eng. 2006, 19:204-208.

34. Anthony JW, Bideaux RA, Bladh KW, Nichols MC: Handbook of Mineralogy. Chantilly: Mineralogical Society of America; 2003.

35. International Programme on Chemical Safety (IPCS): International Chemical Safety Card 0751 - Copper (II) sulfate. Retrieved 27/11/2012. http://www. inchem.org/documents/icsc/icsc/eics0751.htm.

36. Solubility Product Constants. http://www.ktf-split.hr/periodni/en/abc/kpt.html.

37. Kamyshny A Jr: Goldschmidt abstracts 2010 - solubility of cycloctasulfur in water as a function of temperature, salinity and sulfide concentration. Geochim Cosmochim Acta 2010, 74:A493.

38. Cernosek Z, Holubova J, Cernoskova E, Ruzicka A: Sulfur-a new information on this seemingly well-known element. J Non-oxide Glasses 2009, 1:38-42.

39. Pryor WA: The kinetics of the disproportionation of sodium thiosulfate to sodium sulfide and sulfate. J Am Chem Soc 1960, 82:4794-4797.

40. Pryor WA: Kinetics of the oxidation of $m$-toluic acid to isophthalic acid by aqueous sulfur solutions. J Am Chem Soc 1958, 80:6481-6486.

41. Parker AJ, Kharasch N: The scission of the sulfur-sulfur bond. Chem Rev 1959, 59:583-628.

42. Scherrer P: Bestimmung der grösse und der inneren struktur von kolloidteilchen mittels röntgenstrahlen. Nachr Ges Wiss Göttingen 1918, 26:98-100. 
43. Zhang YC, Qiao T, Hu XY: A simple hydrothermal route to nanocrystalline CuS. J Cryst Growth 2004, 268:64-70.

44. Evans H, Konnert J: Crystal structure refinement of covellite. Am Mineral 1976, 61:996-1000

45. Folmer JCW, Jellinek F: The valence of copper in sulphides and selenides: An X-ray photoelectron spectroscopy study. J Less Common Met 1980, 76:153.

46. Pattrick RAD, Mosselmans JFW, Charnock JM, England KER, Helz GR, Garner $C D$, Vaughan DJ: The structure of amorphous copper sulfide precipitates: an X-ray absorption study. Geochim Cosmochim Acta 1997, 61:2023-2036.

47. Matysina ZA: The relative surface energy of hexagonal close-packed crystals. Mater Chem Phys 1999, 60:70-78.

48. Peng XG, Manna L, Yang WD, Wickham J, Scher E, Kadavanich A, Alivisatos AP: Shape control of CdSe nanocrystals. Nature 2000, 404:59-61.

49. Yap PL, Auyoong YL, Kutty MG, Timpe O, Behrens M, Abd Hamid SB: Facile remediation method of copper sulfide by nitrogen pre-treatment. Advanced Materials Research 2012, 361:1445-1450.

doi:10.1186/1752-153X-7-67

Cite this article as: Auyoong et al: Optimization of reaction parameters in hydrothermal synthesis: a strategy towards the formation of CuS

hexagonal plates. Chemistry Central Journal 2013 7:67.

\section{Publish with ChemistryCentral and every scientist can read your work free of charge \\ "Open access provides opportunities to our colleagues in other parts of the globe, by allowing anyone to view the content free of charge." \\ W. Jeffery Hurst, The Hershey Company. \\ - available free of charge to the entire scientific community \\ - peer reviewed and published immediately upon acceptance \\ - cited in PubMed and archived on PubMed Central \\ - yours - you keep the copyright \\ Submit your manuscript here: \\ http://www.chemistrycentral.com/manuscript/<smiles>c1ccccc1</smiles> Chemistry Central}

